\title{
The Micro Origins of International Business-Cycle Comovement $t^{\dagger}$
}

\author{
By Julian di Giovanni, Andrei A. Levchenko, and Isabelle Mejean*
}

\begin{abstract}
This paper investigates the role of individual firms in international business-cycle comovement using data covering the universe of French firm-level value added and international linkages over the period 1993-2007. At the micro level, trade and multinational linkages with a particular foreign country are associated with a significantly higher correlation between a firm and that foreign country. The impact of direct linkages on comovement at the micro level has significant macro implications. Without those linkages the correlation between France and foreign countries would fall by about 0.098, or one-third of the observed average correlation of 0.291 in our sample of partner countries. (JEL F14, F23, F44, F62, L14)
\end{abstract}

Countries that exhibit greater bilateral trade and multinational production linkages have more correlated business cycles (Frankel and Rose 1998; Kleinert, Martin, and Toubal 2015). While the empirical literature has repeatedly confirmed the trade-comovement relationship in the data, its meaning is not well understood, either empirically or quantitatively. Taken at face value, the positive association between bilateral trade and multinational linkages and comovement is often interpreted as evidence of transmission of shocks across countries through those linkages.

The empirical literature has faced two related challenges. The first is the critique by Imbs (2004) that countries that trade more with each other are similar in other ways, and thus subject to common shocks. Under an extreme version of this view, the trade linkage variable in the Frankel-Rose specification does not reflect the

\footnotetext{
* di Giovanni: ICREA-Universitat Pompeu Fabra, Barcelona GSE, Ramon Trias Fargas 25-27, 08005, Barcelona, Spain, CREI, and CEPR (email: julian.digiovanni@upf.edu); Levchenko: University of Michigan, 611 Tappan Street, Ann Arbor, MI 48109, NBER, and CEPR (email: alev@umich.edu); Mejean: CREST, École Polytechnique, Université Paris-Saclay, Route de Saclay 91128 Palaiseau Cedex, France, and CEPR (email: isabelle. mejean@polytechnique.edu). This paper was accepted to the AER under the guidance of Mark Aguiar, Coeditor. We would like to thank anonymous referees, Jean Imbs, Silvana Tenreyro, and workshop participants at several institutions for helpful discussions, and Eda Gulsen for expert research assistance. Di Giovanni gratefully acknowledges the European Research Council (ERC) under the European Union's Horizon 2020 research and innovation programme (grant agreement no. 726168), and the Spanish Ministry of Economy and Competitiveness, through the Severo Ochoa Programme for Centres of Excellence in R\&D (SEV-2015-0563) for financial support. Mejean gratefully acknowledges support from a public grant overseen by the French National Research Agency (ANR) as part of the "Investissements d'Avenir" program (Idex grant agreement ANR-11-IDEX-0003- 02/Labex ECODEC ANR-11-LABEX-0047 and Equipex reference: ANR-10-EQPX-17, Centre d'accès sécurisé aux données (CASD)), and the European Research Council (ERC) under the European Union's Horizon 2020 research and innovation programme (grant agreement no. 714597). The authors declare that they have no relevant or material financial interests that relate to the research described in this paper.

${ }^{\dagger}$ Go to https://doi.org/10.1257/aer.20160091 to visit the article page for additional materials and author disclosure statement(s).
} 
intensity of transmission of shocks, but rather is simply a stand-in for the prevalence of common shocks. The second is that even if one accepts the transmission of shocks interpretation of the Frankel-Rose result, the coarse nature of the cross-country setting makes it difficult to learn about the micro underpinnings of the trade-comovement relationship. This lack of understanding is reinforced by the quantitative literature, which has struggled to capture the trade-comovement relationship. Kose and Yi (2006) and Johnson (2014) show that even quite sophisticated international real business cycle (IRBC) models fail to generate the observed positive association, dubbing it the "trade-comovement puzzle." 1

Until now the properties of international comovement at the firm level, or its aggregate implications, have by and large not been studied. This paper provides a forensic account of international comovement at both the micro and macro levels using data covering the universe of French firm-level value-added, destination-specific imports and exports, and cross-border ownership over the period 1993-2007. Examining cross-border comovement at the firm level has two advantages relative to the traditional approach of looking directly at GDP correlations. First, at the micro level, the data allow for precise measurement of trade and multinational linkages, by firm $\times$ country, and to control for common shocks using appropriate fixed effects. This overcomes the common shocks critique and lets us establish much more firmly that the positive trade-comovement relationship is due at least in part to transmission of shocks at the firm level.

Second, at the macro level, our approach allows us to capture the aggregate comovement implications of heterogeneity across firms in both size and the extent of international linkages. Larger firms are disproportionately more likely to trade internationally and own affiliates in foreign countries. Indeed, in most countries international trade flows are dominated by only a handful of large firms. An emerging research agenda in closed-economy macro has argued convincingly that modeling and measuring shocks at the micro level (to firms and sectors), and linkages between them, is essential for understanding aggregate fluctuations. ${ }^{2}$ If large firms and firm-to-firm linkages matter for aggregate fluctuations, a natural conjecture is that they will matter as much if not more for cross-border comovement.

We begin by estimating a specification inspired by Frankel and Rose (1998), which relates the correlation of firm total value-added growth with foreign GDP growth to firm-level direct linkages to that country. The data contain, for each firm and potential partner country, four types of direct linkages: (i) importing from it; (ii) exporting to it; (iii) being a France-based affiliate of a multinational firm

\footnotetext{
${ }^{1}$ The literature on multinationals and international business-cycle comovement is more limited, but shares this feature. Kleinert, Martin, and Toubal (2015) show that French regions that contain more multinationals from a particular foreign country are more correlated with that country. However, Cravino and Levchenko (2017) show that the observed multinational presence alone cannot generate the level of positive comovement found in the data. Liao and Santacreu (2015) develop a model in which technology shocks are transmitted between countries through changes in the mix of imported inputs, and show that allowing for the extensive margin of trade yields more promising results.

${ }^{2}$ Gabaix (2011), di Giovanni and Levchenko (2012), and Carvalho and Grassi (2015) develop models in which aggregate fluctuations arise from shocks to individual firms, because the firm-size distribution is extremely fat-tailed (Zipf's law). Acemoglu et al. (2012) and Carvalho and Gabaix (2013) argue that sectoral shocks lead to aggregate fluctuations through interconnections between sectors. Di Giovanni, Levchenko, and Mejean (2014), Atalay (2017), Friberg and Sanctuary (2016), and Magerman et al. (2016) provide corresponding empirical evidence on the role of shocks to firms and sectors in aggregate fluctuations.
} 
headquartered in that country; (iv) being a French firm with a foreign affiliate in that country. Because the sample includes many firms and countries, estimation controls for both firm and country effects. Country effects in particular absorb the common aggregate shocks affecting France and each foreign country.

In a sample of firm-level correlations with ten large trading partners of France, trade linkages at the firm level are significantly associated with increased comovement between an individual firm and the country with which it trades. An import link increases the correlation by 0.013 and an export link by 0.005 . This is large relative to the average correlation between an individual firm and foreign GDP, which is 0.024 for directly connected firms, and essentially zero for non-directly connected ones. By a similar token, affiliates of foreign multinationals operating in France have a 0.010 higher correlation with their source countries.

At the same time, the empirical exercise reveals the importance of common shocks in the data. In a specification that omits the ten country fixed effects but still includes the approximately 1 million firm effects, the coefficients on the direct linkages variables are two to five times larger in magnitude and all strongly statistically significant. This underscores both the empirical relevance of common shocks, and how important it is to control for them in "gravity-macro" analyses of the effects of bilateral trade and capital flows linkages on aggregate outcomes. Nonetheless, the results when controlling for common shocks still provide clear evidence of transmission through direct linkages at the firm level.

We then use the sector-level input-output table together with firm-level information on input purchases and domestic sales to construct proxies for indirect linkages between French firms and foreign markets. The measures, inspired by the "network effect" propagation terms in Acemoglu, Akcigit, and Kerr (2016), capture the intensity with which a French firm interacts with internationally connected firms. The downstream indicator reflects whether a firm buys intermediate inputs from firms that import from a particular country. The upstream indicator captures whether a firm sells its output to firms that export to a particular country. Both of these measures are firm- and foreign-country-specific. We augment the main specification with these indirect linkage terms, and show that the downstream indirect linkages do matter significantly for firm-level comovement with foreign markets. Firms that buy inputs from importers from a particular country are more correlated with that country. The evidence on upstream linkages is more mixed, with coefficients differing in sign and significance depending on specification.

The second half of the analysis examines the macro implications of the micro-level findings. We start with the observation that the aggregate business-cycle correlation between France and another country is simply an appropriately weighted sum of the correlations of firm-level total value added with that country. The aggregate business-cycle correlation between France and each country can thus be written as a sum of two terms: the part due to the directly connected firms, and the part due to the not directly connected firms. For the ten largest trading partners of France in our sample, we show that the large directly connected firms are important in accounting for aggregate comovement. For a typical foreign partner country, the directly connected firms represent only about 8 percent of all firms in our dataset, but account for 56 percent of total value added. The directly connected firms are also unconditionally more correlated with the foreign country. Together these two facts imply that 
the directly connected firms account for 67 percent of the aggregate business-cycle correlation observed in the data for the average country.

We then use the conditional relationship between direct linkages and firm-level correlations to compute the change in the aggregate correlation between France and each foreign country that would occur if direct linkages at the firm level disappeared. This accounting exercise combines information on the change in the correlation at the firm level from the regression estimates with firm-level weights. If direct linkages at the firm level were severed, the aggregate correlation would fall by 0.098 on average in our sample of 10 partner countries. This is a nonnegligible change relative to the observed correlations between France and its main trading partners of 0.291 on average over this period. Since our data allow us to estimate the coefficients on trade and multinational links separately, we can also check which ones matter more for generating aggregate comovement. It turns out that the trade linkages are about 10 times more important in generating aggregate comovement than multinational linkages, accounting for 0.090 of the overall 0.098 effect.

Augmenting the aggregate impact with the indirect linkage estimates, we show that indirect linkages are quantitatively important as well. Accounting for indirect linkages implies that aggregate correlation would fall by 0.199 on average in the whole economy if links to the foreign country were severed. Thus, direct and indirect linkages together can account for two-thirds of the average 0.291 observed aggregate correlation.

To summarize, on the one hand the data point clearly to the presence of common shocks, implying that it is imperative to control for them in the empirical exercise. On the other hand, even after controlling for common shocks, there is still substantial evidence of transmission of shocks through trade and multinational linkages. Among those linkages, trade linkages appear to matter more than multinational ones, especially in aggregate. Downstream indirect input linkages are both statistically robust and quantitatively important as well.

Our paper contributes to the empirical literature on international business cycle comovement. Studies building on Frankel and Rose (1998) have confirmed the positive association between trade and comovement and examined how it differs across types of goods trade and subsamples of countries (see, e.g., Baxter and Kouparitsas 2005; Calderon, Chong, and Stein 2007; Ng 2010; Blonigen, Piger, and Sly 2014; Liao and Santacreu 2015). While the existing empirical literature has almost exclusively used GDP correlations as the outcome variable, there has been comparatively little work on international comovement at more disaggregated levels. Di Giovanni and Levchenko (2010) estimate the relationship between bilateral trade, input linkages, and sector-level correlations. This paper's contribution is to examine the trade-comovement relationship at the firm level, and to derive the aggregate implications based on micro-level estimates. In this respect, it shares some features with recent papers such as Boehm, Flaaen, and Pandalai-Nayer (2015), Kurz and Senses (2016), and Cravino and Levchenko (2017), who perform related exercises.

The empirical literature on the cross-country business-cycle synchronization has also examined other mechanisms, such as sectoral specialization (see, e.g., Clark and van Wincoop 2001; Kalemli-Ozcan, Sorensen, and Yosha 2001; Imbs 2004) or financial integration (see, e.g., Morgan, Rime, and Strahan 2004; Imbs 2006; Kalemli-Ozcan, Papaioannou, and Peydró 2013, among others). Our approach 
allows us to control for these country characteristics as well as common aggregate shocks, thus providing a precise estimate of the impact of firm-level real linkages on business-cycle comovement.

An important research agenda, going back to Backus, Kehoe, and Kydland (1995), attempts to understand the positive GDP comovement across countries using representative firm models in which all shocks are aggregate. Later developments in this literature explored the role of the production structure, such as input-output linkages (Burstein, Kurz, and Tesar 2008; Arkolakis and Ramanarayanan 2009) or firm heterogeneity (Ghironi and Melitz 2005; Alessandria and Choi 2007) but have similarly been confined to considering only the role of aggregate productivity shocks in generating cross-country business-cycle comovement. Our results suggest that to fully understand the impact of transmission of shocks for aggregate comovement, a quantitative framework must feature a realistic micro structure that combines granularity in the firm-size distribution and systematic heterogeneity among firms in trade and multinational linkages.

The rest of the paper is organized as follows. Section I lays out the conceptual framework and the empirical exercises performed in the paper. Section II describes the data, and Section III the results. Section IV concludes.

\section{Conceptual Framework}

Total value added $X_{t}$ by all French firms in year $t$ is by definition given by $X_{t} \equiv \sum_{f \in I_{t}} x_{f t}$, where $x_{f t}$ is defined as the value added of firm $f$ in year $t$, and $I_{t}$ is the set of firms $f$ operating at $t$. The growth rate of aggregate value added is then defined simply as $\gamma_{A t}=X_{t} / X_{t-1}-1$, where we assume that $X_{t-1}$ and $X_{t}$ are the aggregate value added of all firms that exist both at $t-1$ and $t$, i.e., we restrict attention to the intensive margin of aggregate value-added growth. Online Appendix A develops a complete decomposition of the total value-added growth into extensive and intensive margins, and presents the results for the relative contributions of the extensive and intensive margins to aggregate comovement between France and its main trade partners. The main result is that the large majority of aggregate comovement is accounted for by the intensive margin, with the extensive margin playing only a minor role. ${ }^{3}$

The growth rate of aggregate value added can be written as a function of individual firm growth rates and firm shares:

$$
\gamma_{A t}=\sum_{f} w_{f t-1} \gamma_{f t}
$$

where $\gamma_{f t}$ is the growth rate of value added of firm $f$, and $w_{f t-1}$ is the share of $f$ 's value added in total French value added.

\footnotetext{
${ }^{3}$ These results are not inconsistent with the empirical findings in Liao and Santacreu (2015), who show that the extensive margin of trade is positively correlated with bilateral comovement. Those results relate the cross-sectional variation in the number of products traded between country pairs to bilateral business-cycle comovement. Our extensive margin is the aggregate contribution of entry and exit of French firms from year to year, an object that has no close relationship to the cross-country differences in the number of traded varieties.
} 
The object of interest is the correlation between French aggregate growth and foreign GDP growth. Let $\gamma_{\mathcal{C} t}$ be the GDP growth of a foreign country $\mathcal{C}$ between $t-1$ and $t$. This correlation is given by

$$
\rho\left(\gamma_{A t}, \gamma_{\mathcal{C} t}\right)=\frac{\operatorname{cov}\left(\gamma_{A t}, \gamma_{\mathcal{C} t}\right)}{\sigma_{A} \sigma_{\mathcal{C}}}
$$

where $\sigma_{A}$ is the standard deviation of French GDP growth, and $\sigma_{\mathcal{C}}$ is the standard deviation of country $\mathcal{C}$ growth.

Combining (1) and (2), the correlation between France and $\mathcal{C}$ at time $t$ can be written as

$$
\begin{aligned}
\rho\left(\gamma_{A t}, \gamma_{\mathcal{C} t}\right) & =\frac{\operatorname{cov}\left(\sum_{f} w_{f t-1} \gamma_{f t}, \gamma_{\mathcal{C} t}\right)}{\sigma_{A} \sigma_{\mathcal{C}}} \\
& =\sum_{f} w_{f t-1} \frac{\sigma_{f}}{\sigma_{A}} \rho\left(\gamma_{f t}, \gamma_{\mathcal{C} t}\right),
\end{aligned}
$$

where $\sigma_{f}$ is the standard deviation of $\gamma_{f t}$.

While simply an identity, (4) states the key premise of the paper: the aggregate correlation between the French economy and another country is an appropriately weighted sum of the firm-level correlations. The substantial literature on international comovement has studied empirically and theoretically the left-hand side of this equation: the aggregate business-cycle comovement. This paper provides a picture of aggregate comovement by examining instead the components of the right-hand side. We proceed by analyzing first the properties of the individual firmlevel correlations $\rho\left(\gamma_{f t}, \gamma_{\mathcal{C} t}\right)$, and then the consequences of aggregation across firms.

\section{A. Micro Evidence}

To establish whether the direct trade and multinational linkages at the firm level to a particular foreign country are associated with a higher correlation between the firm and that foreign country, we estimate the following specification:

$$
\begin{aligned}
\rho\left(\gamma_{f t}, \gamma_{\mathcal{C} t}\right)= & \alpha+\beta_{1} E X_{f, \mathcal{C}}+\beta_{2} I M_{f, \mathcal{C}}+\beta_{3} A F F_{f, \mathcal{C}}+\beta_{4} H Q_{f, \mathcal{C}} \\
& +\delta_{f}+\delta_{\mathcal{C}}+\eta_{f, \mathcal{C}} .
\end{aligned}
$$

In equation (5), the correlation between a firm and a foreign market $\mathcal{C}$ is related to binary indicators of whether the firm exports to there $\left(E X_{f, \mathcal{C}}\right)$, imports from there $\left(I M_{f, \mathcal{C}}\right)$, is a French multinational with affiliates in $\mathcal{C}\left(H Q_{f, \mathcal{C}}\right)$, or is an affiliate of a foreign multinational headquartered in $\mathcal{C}\left(A F F_{f, \mathcal{C}}\right)$.

Our firm-level specification leads to qualitatively new insights relative to the traditional cross-country empirical model pioneered by Frankel and Rose (1998). First, it admits both firm and country effects, allowing us to establish that trade and multinational linkages are indeed a source of transmission of shocks rather than simply a 
stand-in for the presence of common shocks. Since all firms in this specification are in France, country effects capture the common correlation of all firms in France with country $\mathcal{C}$, and thus absorb the correlation induced by common shocks that affect both France and that country.

At the same time, the country effects will also capture the correlation that is due to transmission of shocks between a foreign country and France if that transmission manifests itself at the aggregate level. For example, if German shocks transmit to French wages or the overall price levels, these shocks will affect all the firms in France and thus will get picked up by the German country effect. In other words, while the country effects control for common shocks, they in principle also absorb some part of the impact of shock transmission, to the extent that the foreign shocks affect all firms irrespective of their own direct connectedness. As a result, the $\beta$ coefficients in equation (5) can be thought of as a lower bound on the importance of transmission for comovement. By the same token, the finding that country effects play a large role is not necessarily evidence that transmission is unimportant, as some transmission will be picked up by those country effects.

Second, estimation at the firm level reveals the micro underpinnings of the aggregate relationship. Observing cross-border links at the firm level allows us to establish with forensic precision the role of each type of trade and multinational relationship in international comovement. With very few exceptions (e.g., Kleinert et al. 2015), existing papers do not combine information on both trade and multinational linkages in the same specification. This may be important: if both types of linkages potentially matter, not including them will lead to omitted variable bias. Firm effects also control for a range of characteristics that vary at the firm level and potentially affect its average comovement with the rest of the world, such as its volatility, size, primary industry of operation, capital or skill intensity, access to external finance, R\&D intensity, domestic linkages, and so on.

Indirect Linkages. - It may be that even firms not directly connected to a particular foreign country comove with that country through indirect linkages, that is, interactions inside the French economy induced by the directly connected firms. A complete account of all indirect linkages is not possible in this empirical setting, as those linkages can take a variety of forms, from purchases/sales of intermediate inputs by the directly connected firms to changes in factor and goods prices in general equilibrium. Nonetheless, we attempt to capture one type of indirect linkage, that can be potentially measured: indirect linkages through input-output relationships inside the French economy. To that end, we construct the following firm-specific indices of indirect linkages:

$$
\begin{aligned}
D S_{f, j, \mathcal{C}} & =\operatorname{INPUTINT}_{f} \sum_{i} I O_{i j} \frac{N I M_{i, \mathcal{C}}}{N_{i}}, \\
U S_{f, j, \mathcal{C}} & =\operatorname{DOMINT}_{f} \sum_{i} I O_{j i} \frac{N E X_{i, \mathcal{C}}}{N_{i}} .
\end{aligned}
$$

In these expressions, $i$ and $j$ index sectors, and firm $f$ belongs to sector $j$. The term $I O_{i j}$ is the domestic direct requirement coefficient of the 1995 French input-output 
matrix, defined as the share of spending on domestically produced sector $i$ inputs in production in sector $j$. Further, $N I M_{i, \mathcal{C}}$ is the number of French firms in sector $i$ that import from $\mathcal{C}, N E X_{i, \mathcal{C}}$ is the number of French firms in sector $i$ that export to $\mathcal{C}$, and $N_{i}$ is the total number of firms in sector $i$. Each of these numbers is computed excluding firm $f$ itself (which is obviously only relevant if $i=j$ ), and thus are in that sense firm-specific, but we suppress the dependence of those values on $f$ to

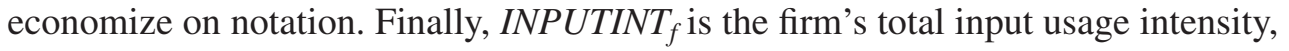
defined as the total material input spending divided by material input spending plus wage bill, averaged across years; DOMINT $T_{f}$ is the domestic sales intensity, defined as the share of firm $f$ sales that goes to the domestic market, averaged across years.

These indices are heuristic, but inspired by the formulation of the "network effect" propagation of terms in Acemoglu, Akcigit, and Kerr (2016). The $D S_{f, j, \mathcal{C}}$ indicator, short for "downstream," is meant to capture the fact that firms in sector $j$ buy inputs from other sectors $i$ in the economy. To the extent that sector $i$ is populated by firms that import from country $\mathcal{C}$, country $\mathcal{C}$ shocks will propagate to input-buying firms in $j$ through their input purchases of $i$. For any individual sector $i$, the term in the summation, $I O_{i j} \frac{N I M_{i, \mathcal{C}}}{N_{i}}$, will be high either if $j$ uses a lot of sector $i$ inputs $\left(I O_{i j}\right.$ is high), or if a high fraction of sector $i$ firms import from $\mathcal{C}$. The summation aggregates this information across all the input-supplying sectors of $j$, and multiplies it by the firm-specific input intensity, since the importance of downstream linkages will be higher for firms that spend a lot on inputs.

The $U S_{f, j, \mathcal{C}}$ ("upstream") indicator is meant to capture the fact that firms in sector $j$ supply inputs to other sectors $i$, and thus will be affected by whether the sector $i$ buying its inputs has a large population of directly connected firms. Export opportunities in sector $i$ to country $\mathcal{C}$ will propagate to sector $j$ as an increase in exports from $i$ to $\mathcal{C}$ will raise demand for sector $j$ inputs. For an individual output sector $i$, the term $I O_{j i} \frac{N E X_{i, \mathcal{C}}}{N_{i}}$ will be high if either $i$ uses a lot of $j$ inputs, or if a large share of firms in $i$ export to $\mathcal{C}$. The summation across sectors is multiplied by the share of firm $f$ 's sales in the domestic market, since if $f$ does not sell much of its output in France, by construction it must be a relatively unimportant supplier of inputs to the French market.

The indices are constructed using sector-level information by necessity, as there is yet no firm-level input-output matrix available for France. If we had firm-level information, these indices would have a much simpler form, and would exploit information on whether firm $f$ sources inputs from directly connected firms, or supplies inputs to directly connected firms. ${ }^{4}$

Note that while these formulations appear the most natural to us, one can think of other transmission mechanisms that might be at work. For example, one can build a "horizontal" transmission indicator that instead of counting the number of importing firms in the input-supplying sector, counts the number of exporting firms.

\footnotetext{
${ }^{4}$ If we had a firm-to-firm IO matrix, we could construct the simple index $D S_{f, \mathcal{C}}^{*}=\sum_{g} I O_{g f} I M_{g, \mathcal{C}}$, where $I O_{g f}$ is the share of spending by firm $f$ on inputs supplied by firm $g$ in $f$ 's total output (the firm-to-firm direct requirement coefficient), and $I M_{g, \mathcal{C}}$ is, as defined above, the indicator for whether $g$ imports from $\mathcal{C}$. The "ideal" index $D S_{f, \mathcal{C}}^{*}$ would be a precise measure of whether firm $f$ sources inputs from directly connected firms or not. In the absence of firm-to-firm IO information, INPUTINT $f O_{i j}$ is our best guess for $I O_{g f}$, and $\frac{N I M_{i, \mathcal{C}}}{N_{i}}$ is an estimate for how likely it is that $I M_{g, \mathcal{C}}=1$.
} 
This indicator would be relevant if, for instance, there are capacity constraints and thus greater export opportunities in the input-supplying sector $i$ reduce those firms' domestic supply of inputs. We view those alternative indicators as less compelling and most likely second-order relative to those set out above. Indeed, using the exogenous shock of the 2011 Japanese earthquake, Carvalho et al. (2016) do not find horizontal transmission to be important. An additional question is whether we should also build propagation indices for multinationals and affiliates. In this case, it is also unclear in which way do shocks to multinationals propagate to nondirectly connected firms. To avoid a proliferation of regressors, we favor a more parsimonious specification with only the two indices (6) and (7).

We add these two variables to the baseline specification (5). Thus, we include the indirect linkage indicators alongside the direct linkage indicators and country and firm fixed effects:

$$
\begin{aligned}
\rho\left(\gamma_{f t}, \gamma_{\mathcal{C} t}\right)= & \alpha+\beta_{1} E X_{f, \mathcal{C}}+\beta_{2} I M_{f, \mathcal{C}}+\beta_{3} A F F_{f, \mathcal{C}}+\beta_{4} H Q_{f, \mathcal{C}} \\
& +\beta_{5} D S_{f, j, \mathcal{C}}+\beta_{6} U S_{f, j, \mathcal{C}}+\delta_{f}+\delta_{\mathcal{C}}+\eta_{f, \mathcal{C}} .
\end{aligned}
$$

\section{B. From Micro to Macro}

Next, we investigate the macroeconomic implications of these micro findings. The aggregate correlation as written in (4) is additive in the individual firm-level correlations with foreign GDP, and thus can be decomposed easily into the various components. Since we are interested in the impact of individual firms on aggregate correlations, we can decompose the aggregate growth rate into the contribution of two sets of firms: the directly connected and the not directly connected to a particular country,

$$
\gamma_{A t}=\sum_{f} w_{f t-1} \gamma_{f t}=\sum_{f \in I_{\mathcal{C}}} w_{f t-1} \gamma_{f t}+\sum_{f \in I_{\mathcal{C}}^{c}} w_{f t-1} \gamma_{f t}
$$

where $I_{\mathcal{C}}$ is the set of firms that satisfy at least one of the four criteria included in estimating equation (5): (i) export to $\mathcal{C}$; (ii) import from $\mathcal{C}$; (iii) is a French affiliate of a multinational based in $\mathcal{C}$; or (iv) is part of a French multinational that has affiliates in $\mathcal{C}$. Correspondingly, $I_{\mathcal{C}}^{c}$ is the complement of that set of firms. Plugging (9) into (3), the aggregate comovement decomposes additively into two components, one due to the directly connected firms, and the other due to the rest:

$$
\rho\left(\gamma_{A t}, \gamma_{\mathcal{C} t}\right)=\frac{\sigma_{I_{\mathcal{C}}}}{\sigma_{A}} \rho\left(\sum_{f \in I_{\mathcal{C}}} w_{f t-1} \gamma_{f t}, \gamma_{\mathcal{C} t}\right)+\frac{\sigma_{I_{\mathcal{C}}^{c}}}{\sigma_{A}} \rho\left(\sum_{f \in I_{\mathcal{C}}^{c}} w_{f t-1} \gamma_{f t}, \gamma_{\mathcal{C} t}\right)
$$

where $\sigma_{I_{\mathcal{C}}}^{2}=\operatorname{var}\left(\sum_{f \in I_{\mathcal{C}}} w_{f t-1} \gamma_{f t}\right)$ is the variance of the combined value added of the directly connected terms, and similarly for $\sigma_{I_{\mathcal{C}}^{c}}^{2}$. By bringing in information on firm weights $w_{f t-1}$, this additive decomposition will provide the first glimpse of whether the directly connected firms combined are a large enough segment of the economy to play an appreciable role in aggregate comovement. 
Of course, this decomposition yields only part of the answer: the direct component can be large either because the directly connected firms are large, or because they are more correlated. An accounting exercise that uses estimates of equation (5) provides the means of separating the two. For each directly connected firm, we can compute the predicted change in its correlation with country $\mathcal{C}$ if it were no longer connected with $\mathcal{C}$ :

$$
\begin{aligned}
\widehat{\Delta \rho}\left(\gamma_{f t}, \gamma_{\mathcal{C} t}\right)= & -\widehat{\beta_{1}}\left(E X_{f, \mathcal{C}}\right)-\widehat{\beta_{2}}\left(I M_{f, \mathcal{C}}\right) \\
& -\widehat{\beta_{3}}\left(A F F_{f, \mathcal{C}}\right)-\widehat{\beta_{4}}\left(H Q_{f, \mathcal{C}}\right) .
\end{aligned}
$$

As an example, if firm $f$ only exported to $\mathcal{C}$ and had no other links, the predicted change in the correlation between $f$ and $\mathcal{C}$ is simply $-\hat{\beta}_{1}$. The formulation (11) allows for every combination of different types of direct links, and turns off all the existing ones at the same time.

Combining (11) with (4), the predicted change in the aggregate business-cycle correlation between France and $\mathcal{C}$ if all cross-border links were severed is

$$
\widehat{\Delta \rho}\left(\gamma_{A t}, \gamma_{\mathcal{C} t}\right)=\sum_{f} w_{f t-1} \frac{\sigma_{f}}{\sigma_{A}} \widehat{\Delta \rho}\left(\gamma_{f t}, \gamma_{\mathcal{C} t}\right) .
$$

For simplicity, this calculation assumes that the severing of the direct links does not have an impact on volatilities either at the firm or the aggregate level, or on firm weights. Since in the data the weights differ across years, we report the values of $\widehat{\Delta \rho}\left(\gamma_{A t}, \gamma_{\mathcal{C}}\right)$ averaged across the sample years below.

We next account for the impact of indirect linkages in a similar way. If all the direct linkages between country $\mathcal{C}$ and France were severed, the $N I M_{i, \mathcal{C}}$ and $N E X_{i, \mathcal{C}}$ terms in (6)-(7) become zero, and as a result in this comparative static, $D S_{f, j, \mathcal{C}}=U S_{f, j, \mathcal{C}}=0 \forall f$. This means that at the firm level, the change in correlation following elimination of links with country $\mathcal{C}$ is

$$
\begin{aligned}
\widehat{\Delta \rho}\left(\gamma_{f t}, \gamma_{\mathcal{C}}\right)= & -\widehat{\beta_{1}}\left(E X_{f, \mathcal{C}}\right)-\widehat{\beta_{2}}\left(I M_{f, \mathcal{C}}\right)-\widehat{\beta_{3}}\left(A F F_{f, \mathcal{C}}\right) \\
& -\widehat{\beta_{4}}\left(H Q_{f, \mathcal{C}}\right)-\widehat{\beta_{5}} D S_{f, j, \mathcal{C}}-\widehat{\beta_{6}} U S_{f, j, \mathcal{C}}
\end{aligned}
$$

and the change in aggregate correlation is still given by (12). Note that in this formulation, correlation of a firm with $\mathcal{C}$ will change even if it has no direct connections to $\mathcal{C}$. By a similar token, even directly connected firms will also exhibit indirect connections to $\mathcal{C}$, and thus the impact in (13) is additive.

An important assumption underlying this accounting exercise is that there are no other general equilibrium interactions that change firm-level correlations when France's openness changes. In particular, the calculation assumes that (i) the change in the correlation of all directly connected firms is given by (11); and (ii) the change in the correlation of all not directly connected firms is accounted for by our measures of indirect linkages through inputs. Thus, it ignores the possibility that a change in France's overall openness has feedback effects that move the firm-level correlations away from what is predicted by the micro-level regressions. These general 
equilibrium feedbacks are potentially interesting but can only be analyzed within a full general equilibrium model structure, and are inaccessible to the regression estimation-type approach adopted here. Nonetheless, by combining micro results on changes in comovement at the firm level with information on the combined size of the connected firms, our results can be used to benchmark the size of the likely aggregate effect, evaluate the relative importance of trade and multinational ownership links, and demonstrate the role of the fact that directly connected firms are systematically larger.

\section{Data and Basic Patterns}

The empirical analysis relies on several firm-level databases. The main object of interest is the correlation between French and foreign GDP growth. At the most disaggregated level, it is measured using a database that covers the universe of French firm sales and value added over the period 1993-2007. The dataset is described in detail in di Giovanni, Levchenko, and Mejean (2014). Importantly, it covers the entire French economy, manufacturing and nonmanufacturing sectors included. We augment it with information on each firm's direct trade and multinational linkages, disaggregated by foreign partner country. Namely, we use Customs data to recover bilateral export and import flows, at the level of each individual firm. Finally, information on the firm ownership linkages is taken from the Liaisons Financieres (LIFI) database, an administrative dataset that provides information about the ownership and nationality of the parent company of firms located in France. Together, these two datasets provide firm-level information on all possible direct links to each individual foreign country, whether through cross-border trade or multinational production. Finally, note that we do not have any information at the plant level.

The value-added data, as well as additional variables, come from the balance sheet information collected from firms' tax forms. The original dataset is quasi-exhaustive. However, the amount of information that has to be provided to the fiscal administration differs according to the firm's size. Namely, the French tax system distinguishes three different regimes, the "normal" regime (Bénéfice Réel Normal (BRN)), the "simplified" regime (Régime Simplifié d'Imposition (RSI)) that is restricted to smaller firms, and the "micro-BIC" regime for entrepreneurs. 5 Throughout the exercise, "micro-BIC" and "RSI" firms are excluded. We do not have enough information for "micro-BIC" firms. We also exclude "RSI" firms, both because their weight in annual sales is negligible and because it is difficult to harmonize these data with the rest of the sample. In 2007, those firms represented less than 4 percent of total sales and about 11 percent of total employment. Thus, our sample represents the bulk of the aggregate French economy. In this sample, it is possible to classify firms according to the sector in which they operate, using information on their NAF code. ${ }^{6}$

\footnotetext{
${ }^{5}$ Under some conditions, firms can choose their tax regime. In 2010, an individual entrepreneur can decide to enroll in the "micro-BIC" regime if its annual sales are below 80,300 euros. Likewise, a firm can choose to participate in the RSI rather than the BRN regime if its annual sales are below 766,000 euros (231,000 euros in services). Those thresholds are adjusted over time, but marginally so.

${ }^{6}$ Nomenclature d'Activités Française (NAF) is the French industrial classification. Our baseline analysis considers the level of aggregation with 114 sectors. This corresponds to the three-digit ISIC (Revision 3 ) nomenclature. We
} 
The information collected by the tax authorities is combined with the firm-level export and import data from the French customs authorities. The datasets can be merged using a unique firm identifier, called SIREN. On top of the firm dimension, the customs data also detail trade flows by their country of destination (for exports) or the country of origin (for imports). This information makes it possible to investigate the heterogeneity of trade linkages within firm across different foreign countries. The customs data are also quasi-exhaustive. There is a declaration threshold of 1,000 euros for annual exports to and annual imports from any given destination outside the European Union. Below the threshold, the customs declaration is not compulsory. Since 1993, intra-EU trade is no longer liable for any tariff, and as a consequence firms are no longer required to submit the regular customs form. A new form has however been created that tracks intra-EU trade. Unfortunately, the declaration threshold for this kind of trade flows in much higher, around 150,000 euros per year in 2010. A number of firms continue declaring intra-EU trade flows below the threshold, however, either because they don't know ex ante that they will not reach the 150,000 euro limit in a given fiscal year, because they apply the same customs procedure for all export markets they serve, or because they delegate the customs-related tasks to a third party (e.g., a transport firm) that systematically fills out the customs form. Below-cutoff trade flows missing from customs data imply that we might underestimate the contribution of direct trade linkages as a driver of aggregate comovement. ${ }^{7}$

The customs data include only trade in goods, and thus firm-level information on trade in services is missing from our analysis. Data on services trade are not collected by customs authorities and are thus considerably more spotty. According to the OECD, in the later half of our sample period services trade accounted for about 20 percent of overall (goods plus services) French imports and exports. Note that our production, goods trade, and multinational indicator data include service sector firms, and our indirect transmission measures in (6) and (7) incorporate domestic service sector linkages. Nonetheless, if there are firms that trade services but not goods, the analysis below understates the extent of direct linkages to foreign countries, and thus the contribution of direct linkages to comovement. It is not clear how large that understatement is, both because we do not observe the magnitude of the service trade at the firm level, and because we do not know whether the comovement impact of service trade is different from that of goods trade.

Finally, the LIFI data are used to get information on (i) whether each French firm is an affiliate of a company headquartered in a particular foreign country, or (ii) whether each firm is, or belongs to, a French company that owns foreign affiliates in a particular foreign country. The LIFI database is constructed by the French statistical institute (INSEE). It is not exhaustive, but it has a good coverage. All

drop NAF sectors 95 (domestic services) and 99 (activities outside France). We also have to neglect the banking sector due to important restructuring at the beginning of the 2000s that makes it difficult to follow individual firms.

${ }^{7}$ We can judge how many exports we are missing by comparing exports declared on tax forms to exports declared to customs. It appears that the problem is relatively minor. In 10 percent of firm-year observations, the tax form reports exports but the customs data do not. These observations account for 7 percent of overall exports. On average, the total exports reported in the tax form but missing from customs (413,000 euros per year) are an order of magnitude smaller than average exports in the whole sample, which are 3,056,000. 
firms with more than 500 employees or a turnover above 60 million euros, whatever their sector of activity, are included in the survey. Moreover, the information is complemented with two additional administrative sources that contain information on a large number of smaller groups. According to the French statistical institute, a firm is an affiliate of a group if the group has the (direct or indirect) majority of voting rights. Using this definition, INSEE identifies firms that own affiliates abroad, together with the nationalities of those affiliates. When the French firm is identified as an affiliate of a foreign company, the nationality of the parent group is recorded as well.

The firm-level correlation coefficients are measured using the time dimension of the value-added data at the firm level. All the firm-level growth rates are deflated with the French GDP deflator. ${ }^{8}$ On the other hand, the empirical strategy does not use the time variability of measures of each firm's direct links with each destination country. To construct the dummies for whether a firm exports $\left(E X_{f, C}\right)$, imports $\left(I M_{f, C}\right)$, has affiliates in the destination $\left(A F F_{f, C}\right)$, or is an affiliate of a foreign multinational firm $\left(H Q_{f, C}\right)$, the time dimension is thus collapsed. Namely, in the baseline analysis the dummy is set to 1 whenever the firm satisfies the corresponding condition over at least one year in the period of observation. ${ }^{9}$ The numbers of firms in each sector that import and export used in the indirect linkage indicators, $N I M_{i, \mathcal{C}}$ and $N E X_{i, \mathcal{C}}$, are defined consistently with the direct linkage indicators and are simply sector-level summations of those, e.g., $N I M_{i, \mathcal{C}}=\sum_{f \in i} I M_{f, \mathcal{C}}$. Throughout the analysis, we winsorize the firm-level growth rates to be bounded by +100 percent and -50 percent to reduce the impact of outliers.

Figure 1 plots the growth rates of aggregate value added, exports, and imports, together with the growth rate of GDP from IMF's International Financial Statistics, and total exports and imports from IMF's Direction of Trade Statistics. The aggregates in our sample of firms mimic the aggregate data from standard sources quite well.

Figure 2 reports the scatterplot of the aggregate correlations with the 10 main trading partner countries implied by our data and the GDP correlations from standard sources, along with a 45-degree line. It is clear that our data capture both the levels and the variation in aggregate comovement extremely well. The correlation between the business-cycle comovement implied by our data and by standard GDP data is 0.992 .

Table 1 presents the basic stylized facts on the composition of the sample. Panel A reports the summary statistics for the whole economy, separately for exporters, importers, affiliates of foreign multinationals, and French firms with foreign affiliates. These four categories are of course not mutually exclusive. The table reports the total numbers of observations and firms, the mean and median value added in each category, and the percentage of total value added captured by each category of firms. There are about a million firms in total. As expected, firms engaged in an international activity represent a minority of the population

\footnotetext{
${ }^{8}$ Firm-level value-added deflators are not available for France. However, since GDP is also deflated with the GDP deflator, real firm-level growth rates defined this way aggregate to the real GDP growth rate as in (1).

${ }^{9}$ The results are robust to instead defining the dummy to equal 1 whenever the firm is connected for at least 50 percent of the years it is present in the sample.
} 

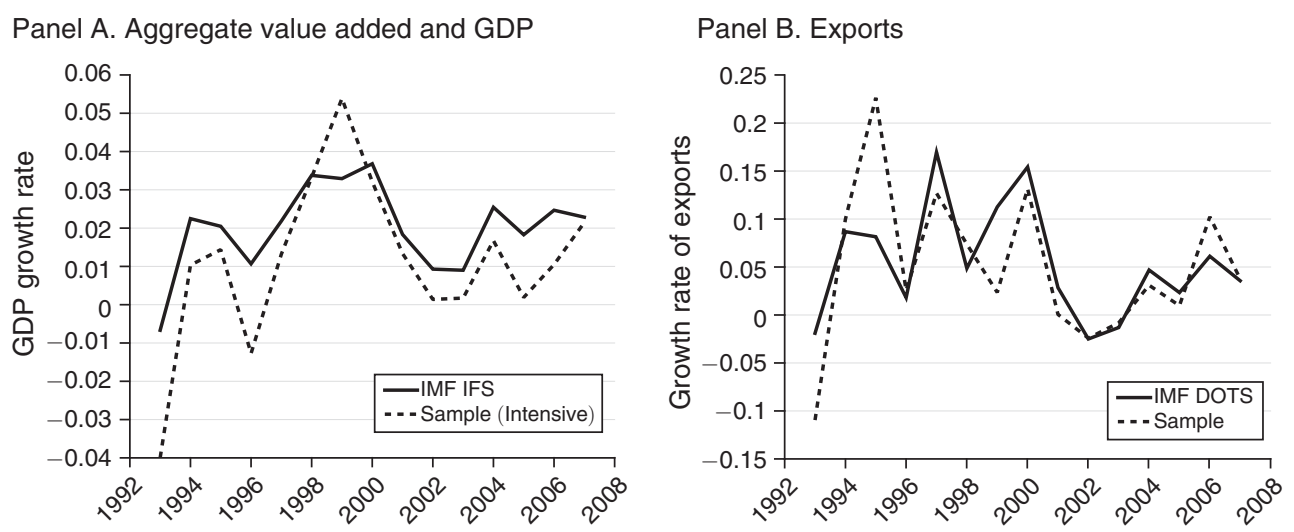

Panel C. Imports

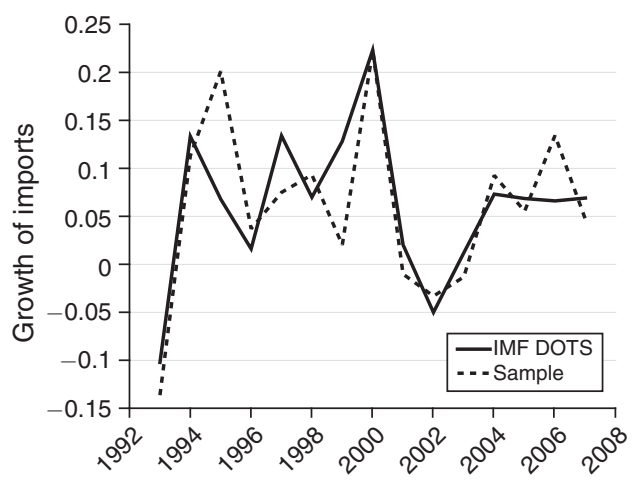

Figure 1. Comparison with Aggregates, Growth Rates

Notes: Panel A presents the time series of the growth rates of total before-tax value added in our data and GDP sourced from the IMF International Financial Statistics. Panels B and C present the growth rates of total exports and imports, respectively, in our sample and sourced from IMF's Direction of Trade Statistics.

of French firms. Around 20 percent of French firms export or import at all. There are an order of magnitude more trading firms than multinationals: about 200,000 importers and exporters, compared to 30,000 affiliates of foreign multinationals, and 1,786 French firms that have foreign affiliates. Each category of the internationally connected firms has larger average value added than purely domestic firms. The largest category on average is French multinationals with affiliates abroad.

More novel is the information in the last column that reports the share of total value added in France that is taken up by each category of firms. These statistics have not, to our knowledge, been previously reported. It turns out that importers account for 72 percent of total French value added, and exporters 71 percent. By contrast, multinational firms account for a smaller share of economic activity, with about 25 percent for foreign affiliates in France, and 14 percent for French-owned multinationals.

Panels $\mathrm{B}$ and $\mathrm{C}$ of Table 1 report the same statistics for the manufacturing sector and its complement. The manufacturing sector is not surprisingly more 


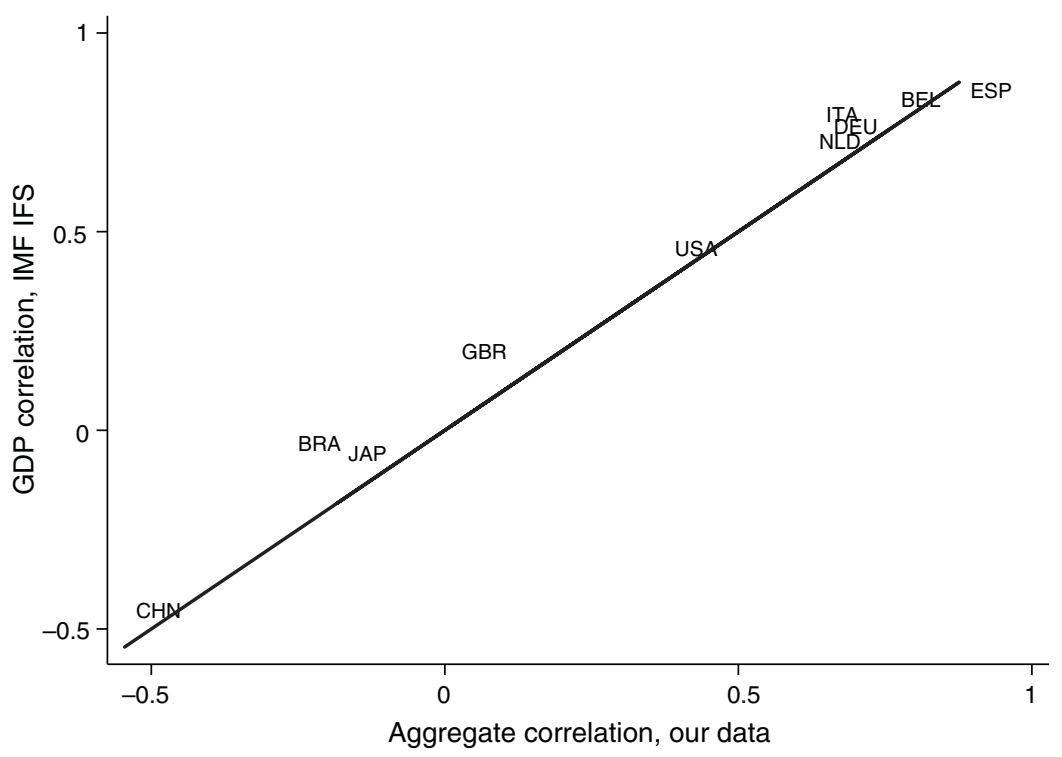

Figure 2. Aggregate Correlations: Comparison to Standard Sources

Note: This figure presents the scatterplot of the aggregate correlations implied by our data and the correlations in GDP from IMF International Financial Statistics, along with a 45-degree line.

TABle 1 -Summary Statistics

\begin{tabular}{lrrrr}
\hline \hline & & Value Added & \\
\cline { 2 - 5 } & $\begin{array}{r}\text { Number } \\
\text { of firms }\end{array}$ & Mean & Median & $\begin{array}{c}\text { Share } \\
\text { in total }\end{array}$ \\
\hline Panel A. Whole economy & & & & \\
All firms & 998,531 & 1,165 & 211 & 1.00 \\
Importers & 189,863 & 3,516 & 515 & 0.72 \\
Exporters & 200,775 & 3,219 & 477 & 0.71 \\
Affiliates of foreign multinationals & 30,654 & 7,061 & 1,335 & 0.25 \\
Firms with foreign affiliates & 1,786 & 65,829 & 2,279 & 0.14 \\
& & & & \\
Panel B. Manufacturing sector & & & & \\
All firms & 145,575 & 2,367 & 382 & 1.00 \\
Importers & 60,395 & 4,444 & 872 & 0.93 \\
Exporters & 66,507 & 4,053 & 754 & 0.93 \\
Affiliates of foreign multinationals & 8,370 & 11,994 & 2,939 & 0.38 \\
Firms with foreign affiliates & 378 & 34,794 & 6,993 & 0.06 \\
& & & & \\
Panel C. Nonmanufacturing sector & & & & \\
All firms & 871,196 & 946 & 191 & 1.00 \\
Importers & 135,161 & 3,116 & 402 & 0.63 \\
Exporters & 139,904 & 2,849 & 384 & 0.62 \\
Affiliates of foreign multinationals & 22,810 & 5,060 & 998 & 0.18 \\
Firms with foreign affiliates & 1,445 & 78,192 & 1,451 & 0.18 \\
\hline
\end{tabular}

Notes: This table reports the summary statistics for the whole economy, the manufacturing and the nonmanufacturing sectors. It reports the number of distinct firms, mean and median value added, and the share of a particular type of firm in total value added. Value added is reported in thousands of euros. The categories of firms are not mutually exclusive.

internationally integrated, with exporters and importers taking up around 93 percent of total manufacturing value added. The nonmanufacturing sector still exhibits substantial cross-border linkages, with over 60 percent of the value added in the 
Table 2-Directly Connected and Not Directly Connected Firms

\begin{tabular}{lrrrrrrrr}
\hline \hline & \multicolumn{3}{c}{ Directly connected } & & \multicolumn{3}{c}{ Not directly connected } \\
\cline { 2 - 3 } & $\begin{array}{c}\text { Number } \\
\text { of firms }\end{array}$ & $\begin{array}{c}\text { Combined } \\
\text { share }\end{array}$ & $\begin{array}{c}\text { Mean } \\
\rho\left(\gamma_{f t}, \gamma_{\mathcal{C} t}\right)\end{array}$ & & $\begin{array}{c}\text { Number } \\
\text { of firms }\end{array}$ & $\begin{array}{c}\text { Combined } \\
\text { share }\end{array}$ & $\begin{array}{c}\text { Mean } \\
\rho\left(\gamma_{f t}, \gamma_{\mathcal{C} t}\right)\end{array}$ \\
\hline Belgium & 113,472 & 0.626 & 0.047 & & 853,812 & 0.374 & 0.007 \\
Brazil & 19,962 & 0.385 & -0.013 & & 947,322 & 0.615 & -0.035 \\
China & 46,930 & 0.489 & -0.064 & & 920,354 & 0.511 & -0.066 \\
Germany & 108,657 & 0.627 & 0.039 & & 858,627 & 0.373 & -0.006 \\
Italy & 105,522 & 0.607 & 0.065 & & 861,762 & 0.393 & 0.027 \\
Japan & 39,500 & 0.478 & -0.042 & & 927,784 & 0.522 & -0.059 \\
Netherlands & 82,369 & 0.590 & 0.065 & & 884,915 & 0.410 & 0.013 \\
Spain & 93,180 & 0.586 & 0.029 & & 874,104 & 0.414 & 0.001 \\
United Kingdom & 84,373 & 0.604 & 0.046 & & 882,911 & 0.396 & 0.021 \\
United States & 80,826 & 0.604 & 0.063 & & 886,458 & 0.396 & 0.044 \\
Average & 77,479 & 0.560 & 0.024 & & 889,805 & 0.440 & -0.005 \\
\hline
\end{tabular}

Notes: This table reports the features of directly connected and not directly connected firms for each partner country. The columns report the number of firms, their combined share in aggregate value added (averaged across years), and the mean correlation between firm value-added growth and the foreign country's GDP growth.

nonmanufacturing sector accounted for by firms that trade, and 18 percent by firms that have multinational linkages. ${ }^{10}$

To get a better sense of the composition of the manufacturing and the nonmanufacturing sectors, online Appendix Table A1 presents the summary statistics by two-digit NAF sector. It reports the share of firms in each sector that exhibit any international linkage (trade or multinational) to any country, the share of the total sectoral value added accounted for by the connected firms, and the share of the sector in the aggregate French value added. Manufacturing corresponds to NAF sectors 15-37. The table highlights the extent to which the manufacturing sector in France is dominated by internationally connected firms. Connected firms represent well over one-half of all firms, and the vast majority of value added in manufacturing. At the same time, the nonmanufacturing sector exhibits substantial cross-border linkages. Connected firms comprise over 80 percent of sectoral value added in Electricity, Gas, and Water Supply, Wholesale and Retail Trade, Transport, and Post and Telecommunications, among others. Multinational presence is an important mode of international integration in these sectors. Indeed, Electricity, Gas, and Water Supply, Wholesale and Retail Trade, Transport, and Post and Telecommunications together account for 85 percent of the value added of foreign multinational affiliates operating in France.

To highlight the similarities and differences between manufacturing and nonmanufacturing sectors, we report the full set of results for each of these separately in the online Appendix.

Table 2 reports the measures of connectedness and firm-level correlations with France's ten major trading partner countries. ${ }^{11}$ For each country, the table presents the number of directly connected firms, the combined share of those firms in total

\footnotetext{
${ }^{10}$ There is a small discrepancy between the total number of firms in panel A and the sum of the numbers of firms in panel B and C, due to the fact that some firms changed sectors during our sample period. Thus, a small minority of firms will appear in both subsamples, in different years.

${ }^{11}$ These countries are nine of the top ten trading partners of France plus Brazil, which we included as a major emerging market to make the sample more diverse and less dominated by European countries.
} 
French value added, and the mean correlation between an individual firm and the GDP growth of that country. The last three columns report the same statistics for the not directly connected firms.

On average, and for most individual countries, there are an order of magnitude fewer directly connected firms than nondirectly connected firms. At the mean, there are 77,000 directly connected, and about 890,000 not directly connected firms. However, the directly connected firms take up on average 56 percent of total French value added. For every single partner country, the directly connected firms are more correlated with the foreign GDP, with an average difference in correlation of 0.029 between the directly connected and not connected firms in this set of countries. ${ }^{12}$ The variation across countries is as expected. In the 4 countries most closely integrated with France (Belgium, Germany, the United Kingdom, and Italy) the directly connected firms account for about 60 percent of all French value added. At the other extreme, the firms directly connected to Brazil, China, and Japan account for 0.385 , 0.489 , and 0.478 of aggregate French value added, respectively.

Online Appendix Table A2 reports the same statistics for the manufacturing and the nonmanufacturing sectors separately. The role of the directly connected firms is greater in manufacturing, where they account for 80 percent of total value added, even though they comprise less than one-quarter of all the firms in this subsample. On the flip side, in the nonmanufacturing sector, firms directly connected to a particular country comprise only 44 percent of the value added on average. The average correlations are slightly higher for the connected manufacturing firms compared to the nonmanufacturing sector.

Table 3 further separates the directly connected firms into importers, exporters, and foreign and domestic multinationals. Once again, the categories are not mutually exclusive. There are large differences between the trading firms and the multinationals. Directly connected exporters and importers account for 45 and 51 percent of aggregate French value added for this set of foreign countries, or the large majority of the total value added of connected firms. By contrast, affiliates of foreign multinationals from an individual country take up 2.3 percent of aggregate value added. French firms with foreign affiliates account for 10.4 percent of aggregate value added. There are also many fewer multinational firms of both kinds than trading firms. Online Appendix Table A3 presents the same statistics for manufacturing and nonmanufacturing. In manufacturing, both importing and exporting firms account for over 70 percent of aggregate value added. In nonmanufacturing, importing is a considerably more important form of direct connectedness than exporting. This is intuitive: even firms that do not produce tradable goods can import. (Recall however that we do not have data on service trade. Thus, these summary statistics understate the nonmanufacturing firms' connectedness through exporting if they engage in substantial service exports.) Another difference between manufacturing and nonmanufacturing is that French multinationals account for a higher share of total value added in nonmanufacturing.

\footnotetext{
${ }^{12}$ The reason that the absolute values of these firm-level correlations are quite small can be gleaned from (4), which shows that aggregate correlation is a combination of firm-level correlations and the ratio of firm-level standard deviations to the aggregate standard deviation. Since firm-level standard deviations of value-added growth are much larger than the aggregate (see, e.g., di Giovanni, Levchenko, and Mejean 2014), the individual correlations must be small to be consistent with the observed aggregate correlations such as those reported in Figure 2.
} 
Table 3-Directly Connected Firms: By Connection Type

\begin{tabular}{|c|c|c|c|c|c|c|}
\hline & \multicolumn{3}{|c|}{ Exporters } & \multicolumn{3}{|c|}{ Importers } \\
\hline & $\begin{array}{l}\text { Number } \\
\text { of firms }\end{array}$ & $\begin{array}{c}\text { Combined } \\
\text { share }\end{array}$ & $\begin{array}{c}\text { Mean } \\
\rho\left(\gamma_{f t}, \gamma_{\mathcal{C} t}\right)\end{array}$ & $\begin{array}{l}\text { Number } \\
\text { of firms }\end{array}$ & $\begin{array}{c}\text { Combined } \\
\text { share }\end{array}$ & $\begin{array}{c}\text { Mean } \\
\rho\left(\gamma_{f t}, \gamma_{\mathcal{C} t}\right)\end{array}$ \\
\hline Belgium & 68,458 & 0.514 & 0.054 & 87,968 & 0.591 & 0.047 \\
\hline Brazil & 12,757 & 0.317 & -0.007 & 9,888 & 0.278 & -0.015 \\
\hline China & 16,560 & 0.372 & -0.050 & 39,157 & 0.445 & -0.068 \\
\hline Germany & 57,200 & 0.493 & 0.050 & 91,181 & 0.603 & 0.040 \\
\hline Italy & 51,904 & 0.471 & 0.073 & 90,364 & 0.583 & 0.066 \\
\hline Japan & 25,072 & 0.401 & -0.042 & 22,959 & 0.413 & -0.036 \\
\hline Netherlands & 42,236 & 0.451 & 0.076 & 63,574 & 0.551 & 0.063 \\
\hline Spain & 52,172 & 0.477 & 0.031 & 72,542 & 0.543 & 0.029 \\
\hline United Kingdom & 46,794 & 0.471 & 0.055 & 64,159 & 0.567 & 0.046 \\
\hline United States & 46,885 & 0.496 & 0.068 & 56,917 & 0.563 & 0.061 \\
\hline Average & 42,004 & 0.446 & 0.031 & 59,871 & 0.514 & 0.023 \\
\hline
\end{tabular}

Affiliates of multinationals

\begin{tabular}{|c|c|c|c|c|c|c|}
\hline & & \\
\hline & $\begin{array}{l}\text { Number } \\
\text { of firms }\end{array}$ & $\begin{array}{c}\text { Combined } \\
\text { share }\end{array}$ & $\begin{array}{c}\text { Mean } \\
\rho\left(\gamma_{f t}, \gamma_{\mathcal{C} t}\right)\end{array}$ & $\begin{array}{l}\text { Number } \\
\text { of firms }\end{array}$ & $\begin{array}{c}\text { Combined } \\
\text { share }\end{array}$ & $\begin{array}{c}\text { Mean } \\
\rho\left(\gamma_{f t}, \gamma_{\mathcal{C} t}\right)\end{array}$ \\
\hline Belgium & 3,527 & 0.016 & 0.039 & 396 & 0.097 & 0.064 \\
\hline Brazil & 4 & 0.000 & -0.016 & 121 & 0.072 & 0.018 \\
\hline China & 89 & 0.000 & -0.110 & 203 & 0.100 & -0.056 \\
\hline Germany & 4,485 & 0.035 & 0.053 & 437 & 0.124 & 0.058 \\
\hline Italy & 1,849 & 0.014 & 0.068 & 374 & 0.124 & 0.035 \\
\hline Japan & 644 & 0.006 & -0.038 & 105 & 0.066 & -0.073 \\
\hline Netherlands & 4,197 & 0.039 & 0.061 & 141 & 0.081 & 0.088 \\
\hline Spain & 957 & 0.006 & 0.039 & 524 & 0.128 & 0.044 \\
\hline United Kingdom & 5,143 & 0.040 & 0.036 & 405 & 0.125 & 0.059 \\
\hline United States & 5,522 & 0.071 & 0.078 & 430 & 0.123 & 0.091 \\
\hline Average & 2,642 & 0.023 & 0.021 & 314 & 0.104 & 0.033 \\
\hline
\end{tabular}

Notes: This table reports the features of different types of directly connected firms. The columns report the number of firms, their combined share in aggregate value added (averaged across years), and the mean correlation between firm value-added growth and the foreign country's GDP growth.

\section{Main Results}

\section{A. Firm-Level Linkages and Correlations}

Table 4 reports the results of estimating (5). The baseline sample includes all firms and performs the analysis on the growth rates of value added. The standard errors are clustered at the firm level. The first column presents the basic estimation without any fixed effects. All four forms of connectedness are positive and strongly significant. The coefficient magnitudes are sizable as well. Importing or exporting is associated with increases in the correlation of 0.029 and 0.035 , respectively. Being a French multinational with affiliates in a particular country increases correlation with that country by 0.023 . Foreign affiliates in France have a 0.028 higher correlation with the parent country. The next column adds firm fixed effects. In this specification, the coefficients are estimated from the variation within the same firm across the ten partner countries. Some of the point estimates fall somewhat, but all four types of connectedness remain positive and strongly significant. ${ }^{13}$

\footnotetext{
${ }^{13}$ There are fewer firms in the regression sample than in the full sample summarized in Table 1 because we drop firms only present in the sample for two years or less, as for those firms the correlation with each foreign country is trivially -1 or 1 .
} 
TABle 4-Main Estimation Results

\begin{tabular}{|c|c|c|c|c|c|c|}
\hline & \multicolumn{5}{|c|}{ Baseline } & \multirow{2}{*}{$\begin{array}{c}\text { Sales } \\
(6)\end{array}$} \\
\hline & (1) & $(2)$ & (3) & (4) & (5) & \\
\hline Importer & $\begin{array}{c}0.029 \\
(0.001)\end{array}$ & $\begin{array}{c}0.025 \\
(0.001)\end{array}$ & $\begin{array}{c}0.013 \\
(0.001)\end{array}$ & $\begin{array}{c}0.013 \\
(0.001)\end{array}$ & $\begin{array}{c}0.012 \\
(0.001)\end{array}$ & $\begin{array}{c}0.018 \\
(0.001)\end{array}$ \\
\hline Exporter & $\begin{array}{c}0.035 \\
(0.001)\end{array}$ & $\begin{array}{c}0.020 \\
(0.001)\end{array}$ & $\begin{array}{c}0.005 \\
(0.001)\end{array}$ & $\begin{array}{c}0.005 \\
(0.001)\end{array}$ & $\begin{array}{c}0.006 \\
(0.001)\end{array}$ & $\begin{array}{c}0.011 \\
(0.001)\end{array}$ \\
\hline French multinational & $\begin{array}{c}0.023 \\
(0.009)\end{array}$ & $\begin{array}{c}0.021 \\
(0.009)\end{array}$ & $\begin{array}{c}0.009 \\
(0.008)\end{array}$ & $\begin{array}{c}0.009 \\
(0.008)\end{array}$ & $\begin{array}{c}0.008 \\
(0.008)\end{array}$ & $\begin{array}{c}0.017 \\
(0.008)\end{array}$ \\
\hline Affiliate of a foreign MNE & $\begin{array}{c}0.028 \\
(0.003)\end{array}$ & $\begin{array}{c}0.028 \\
(0.002)\end{array}$ & $\begin{array}{c}0.010 \\
(0.002)\end{array}$ & $\begin{array}{c}0.010 \\
(0.002)\end{array}$ & $\begin{array}{c}0.009 \\
(0.002)\end{array}$ & $\begin{array}{c}0.014 \\
(0.002)\end{array}$ \\
\hline Observations & $8,363,760$ & $8,363,760$ & $8,363,760$ & $8,363,440$ & $8,363,750$ & $8,928,330$ \\
\hline Adjusted $R^{2}$ & 0.001 & 0.281 & 0.287 & 0.288 & 0.289 & 0.285 \\
\hline Firm fixed effect & No & Yes & Yes & Yes & Yes & Yes \\
\hline Country fixed effect & No & No & Yes & No & No & Yes \\
\hline Country $\times$ region fixed effect & No & No & No & Yes & No & No \\
\hline Country $\times$ sector fixed effect & No & No & No & No & Yes & No \\
\hline Number of Xing links & 403,180 & 403,180 & 403,180 & 403,092 & 403,180 & 418,915 \\
\hline Number of Ming links & 573,347 & 573,347 & 573,347 & 573,222 & 573,347 & 593,338 \\
\hline Number of affiliates & 25,385 & 25,385 & 25,385 & 25,382 & 25,385 & 27,786 \\
\hline Number of HQ links & 3,046 & 3,046 & 3,046 & 3,043 & 3,046 & 3,626 \\
\hline Number of firm fixed effects & & 836,376 & 836,376 & 836,344 & 836,375 & 892,833 \\
\hline Number of country fixed effects & & & 10 & & & 10 \\
\hline Number of country $\times$ region fixed effects & & & & 960 & & \\
\hline Number of country $\times$ sector fixed effects & & & & & 1,090 & \\
\hline
\end{tabular}

Notes: Standard errors clustered at the firm level. This table reports the results of estimating (5) for the whole economy. Dependent variable: $\rho\left(\gamma_{f t}, \gamma_{\mathcal{C}}\right)$. The independent variables are binary indicators for whether the firm imports from a country, exports to it, is an affiliate of a multinational firm from that country, or is a French multinational with affiliates in that country.

The next column adds country effects. Given that this specification adds only ten dummy variables to a regression with over eight million observations, it is remarkable how dramatically the coefficients change. The importer coefficient falls by a factor of two, and the exporter coefficient by a factor of four. Both multinational coefficients decrease and one of them ceases to be statistically significant. This change in the coefficients is a stark illustration of the key tension in the FrankelRose type estimation: disentangling transmission of shocks through trade from common shocks.

By using firm-level data, we can control much better for the common shocks that affect France and its trading partners. The contrast between the specifications with and without country effects shows why it is important to do so. Without country effects (and even after including firm effects), it looks like directly connected firms are strongly correlated with the markets with which they are linked. However, it is clear that a large part of these estimated coefficients is due to the fact that firms are more likely to establish direct links with more correlated markets. Adding country effects controls for the average correlation between French firms and each country, and reduces the estimated impact of direct connectedness considerably.

Nonetheless, column 3 shows that even after controlling for common shocks, direct linkages increase comovement between a firm and the foreign country. A direct importing link is associated with an increase in the firm-level correlation of 0.013, and an exporting link of 0.005. Foreign affiliates in France have 0.010 higher 
correlation with their parent country. Relative to the mean correlation of about 0.024 for the directly connected firms, these coefficients are still sizable.

The rest of the table checks robustness of the results to alternative specifications. Column 4 checks whether the results are driven by omitted regional variation within France, by using foreign country $\times$ département effects instead of foreign country effects. A département is a relatively small French region. There are 96 départements in metropolitan France. These fixed effects control for any differences in correlation between firms in individual French regions and foreign countries. Column 5 instead adds foreign country $\times$ sector effects. These control for any differences between how individual French sectors are correlated with foreign countries. This may matter if sector $j$ in France experiences common shocks with a foreign country. An important special case is that firms belonging to sector $j$ experience common shocks in both France and $\mathcal{C}$, which would translate into a greater correlation of all firms in France that belong to sector $j$ and that foreign country. By a similar token, these fixed effects control for any common correlation between the sectoral price indices in France and each foreign country. In both cases the results are virtually identical to the baseline. Column 6 uses the correlation of firm sales instead of value added. The results are stronger than in the baseline.

Online Appendix Tables A4 and A5 replicate all the results using the samples of manufacturing and nonmanufacturing firms, respectively. All the coefficient magnitudes, patterns of significance, and substantive conclusions are very similar in the two subsamples. These results suggest that while there may be differences between the firms in manufacturing and nonmanufacturing sectors, the ultimate role of direct linkages in generating cross-border comovement at the firm level is quite similar in these two sets of firms.

Table 5 presents the results of estimating (8), that includes indirect linkages. Column 1 presents the baseline specification with firm and country effects. The coefficients on the indirect linkage variables are strongly significant. The coefficient on $D S_{f, j, \mathcal{C}}$ is positive, indicating that foreign shocks transmitted through the firm's input suppliers that import from abroad increase comovement. The coefficient on $U S_{f, j, \mathcal{C}}$ is actually negative (though small in magnitude). To understand the results better, column 2 reports the estimates including country $\times$ sector effects. These will further absorb the variation across sectors, but are very demanding for the purposes of estimating the impact of $D S_{f, j, \mathcal{C}}$ and $U S_{f, j, \mathcal{C}}$, since those indicators rely largely on sector-level variation. The coefficient on $D S_{f, j, \mathcal{C}}$ continues to be positive and significant, but falls considerably in magnitude. The coefficient on $U S_{f, j, \mathcal{C}}$ flips sign and becomes positive and significant. We conclude that the impact of downstream indirect linkages is clearly detectable in the data and robustly positive. By contrast, the importance of upstream linkages (i.e., supplying inputs to exporting firms) is less clear in the data, with the sign and significance sensitive to sample and fixed effects configuration. As a side note, including indirect linkages has virtually no impact on the size and pattern of significance of the direct linkage coefficients.

The finding that the downstream terms are more robustly associated with comovement than the upstream terms lends support to the recent but growing input-output network literature, that tends to emphasize downstream propagation of shocks (Carvalho 2010; Acemoglu et al. 2012; Baqaee 2016; Carvalho et al. 2016; Atalay 2017). 
Table 5-Estimation Results, Taking Indirect Linkages into Account

\begin{tabular}{lcc}
\hline \hline & $(1)$ & $(2)$ \\
\hline Importer & 0.011 & 0.011 \\
& $(0.001)$ & $(0.001)$ \\
Exporter & 0.003 & 0.006 \\
& $(0.001)$ & $(0.001)$ \\
French multinational & 0.009 & 0.008 \\
& $(0.008)$ & $(0.008)$ \\
Affiliate of a foreign MNE & 0.011 & 0.010 \\
& $(0.002)$ & $(0.002)$ \\
$D S_{f, j, C}$ & 0.225 & 0.052 \\
$U S_{f, j, \mathcal{C}}$ & $(0.016)$ & $(0.021)$ \\
& -0.025 & 0.030 \\
Observations & $(0.006)$ & $(0.014)$ \\
Adjusted $R^{2}$ & & \\
Firm fixed effects & $7,866,970$ & $7,866,960$ \\
Country fixed effects & 0.288 & 0.289 \\
Country $\times$ sector fixed effects & Yes & Yes \\
Number of Xing links & Yes & No \\
Number of Ming links & No & Yes \\
Number of affiliates & 401,722 & 401,722 \\
Number of HQ links & 571,234 & 571,234 \\
Number of firm fixed effects & 24,105 & 24,105 \\
Number of country fixed effects & 3,020 & 3,020 \\
Number of country $\times$ sector fixed effects & 786,697 & 1,090 \\
\hline
\end{tabular}

Notes: This table reports the results of estimating (8) for the whole economy. Dependent variable: $\rho\left(\gamma_{f t}, \gamma_{\mathcal{C} t}\right)$. The independent variables are binary indicators for whether the firm imports from a country, exports to it, is an affiliate of a multinational firm from that country, or is a French multinational with affiliates in that country. The downstream indirect linkage indicator $D S_{f, j, \mathcal{C}}$ is defined in (6). The upstream indirect linkage indicator $U S_{f, j, \mathcal{C}}$ is defined in (7).

Online Appendix Table A6 reports the results for the manufacturing and nonmanufacturing samples separately. The manufacturing sample yields larger and more robust coefficients than in the whole economy. However, for the nonmanufacturing sector the pattern is much less consistent. Thus, indirect linkages appear to have their most clear-cut impact in the manufacturing sector. Since the manufacturing and nonmanufacturing sectors are likely to have quite different production functions and market structures, it is not surprising that there are important heterogeneities between sectors in the role of upstream and downstream linkages in generating comovement. Baqaee (2016), Carvalho et al. (2016), and Atalay (2017) show that the sign and strength of propagation of shocks across sectors is determined by the elasticity of substitution across inputs. Grassi (2016) demonstrates that the nature of upstream propagation depends on the market structure.

An interesting question is whether connectedness through trade and multinational links interact in important ways. One may conjecture, for instance, that firms that are part of the same multinational will comove more when they trade compared to firms that trade at arm's length. Table 6 checks this possibility. In order to avoid an excessively large set of interaction terms that is possible between four variables, we condense the set of indicators to two: whether the firm trades with a country and whether it is a part of a multinational with a presence in that country. Column 1 
TABLE 6-Estimation Results: InTERACTION TERMS

\begin{tabular}{lcc}
\hline \hline & $(1)$ & $(2)$ \\
\hline Trade dummy (importer + exporter $\geq 1)$ & 0.011 & 0.011 \\
& $(0.001)$ & $(0.001)$ \\
MNE Dummy (French multinational + affiliate $\geq 1)$ & 0.012 & 0.011 \\
& $(0.002)$ & $(0.004)$ \\
Trade $\times$ MNE Dummy & & 0.001 \\
& & $(0.004)$ \\
Observations & $8,363,760$ & $8,363,760$ \\
Adjusted $R^{2}$ & 0.287 & 0.287 \\
Firm fixed effect & Yes & Yes \\
Country fixed effect & Yes & Yes \\
Number of trade links & 726,920 & 726,920 \\
Number of MNE links & 28,375 & 28,375 \\
Number of firm fixed effects & 836,376 & 836,376 \\
Number of country fixed effects & 10 & 10 \\
\hline
\end{tabular}

Notes: This table reports the results of estimating (5), adding an interaction between trade and multinational status. Dependent variable: $\rho\left(\gamma_{f t}, \gamma_{\mathcal{C}}\right)$. The independent variables are binary indicators for whether the firm trades with a country (imports from it or exports to it), has any multinational links with a country (is an affiliate of a multinational firm from that country, or is a French multinational with affiliates in that country), and the interactions.

checks whether these coarser indicators significantly increase the correlation with the foreign GDP. Column 2 augments the specification with the interaction between the two. It seems that there is no prima facie evidence of an interaction effect: the coefficient is close to zero at 0.001 and insignificant.

To summarize, direct connectedness through importing, exporting, and foreign parent firms is robustly positively associated with greater comovement between a firm and foreign GDP. This effect is identified from the variation across foreign countries within the firm (i.e., by comparing the firm's correlation with a country that it trades with to its correlation with a country that it does not), and after controlling for common aggregate shocks. Thus, this result can be interpreted as robust evidence for transmission of shocks through trade and multinational links. In addition, indirect linkages to downstream firms are robustly positively associated with increased comovement at the firm level, especially in the manufacturing sector.

\section{B. Aggregate Implications}

Table 7 presents the decomposition in (10). For each country, it reports the aggregate correlation $\rho\left(\gamma_{A t}, \gamma_{\mathcal{C} t}\right)$, as well as the two components of the aggregate correlation on the right-hand side of (10), namely those due to the directly and not directly connected firms. On average, 67 percent of the aggregate correlation is taken up by the directly connected firms. The shares are between 0 and 1 in all but one case (the United Kingdom), implying that the direct and indirect components tend to have the same sign as the overall correlation. Online Appendix Table A7 breaks down the sample between manufacturing and nonmanufacturing firms. In the manufacturing sector, the observed correlations are on average higher, and the average share taken up by the directly connected firms is larger at 84 percent.

This decomposition is merely suggestive that direct links are responsible for the observed aggregate comovement. Equation (10) shows that the direct component 
Table 7-Aggregate Correlations: Contributions of Direct and Indirect Terms

\begin{tabular}{lccr}
\hline \hline Country & $\begin{array}{c}\rho_{A} \\
\text { (observed) }\end{array}$ & $\begin{array}{c}\text { Directly } \\
\text { connected }\end{array}$ & $\begin{array}{c}\text { Not directly } \\
\text { connected }\end{array}$ \\
\hline Belgium & 0.758 & 0.519 & 0.239 \\
Brazil & -0.269 & -0.191 & -0.078 \\
China & -0.545 & -0.370 & -0.175 \\
Germany & 0.643 & 0.396 & 0.247 \\
Italy & 0.630 & 0.399 & 0.232 \\
Japan & -0.183 & -0.163 & -0.021 \\
Netherlands & 0.618 & 0.425 & 0.193 \\
Spain & 0.876 & 0.543 & 0.332 \\
United Kingdom & 0.010 & 0.078 & -0.069 \\
United States & 0.372 & 0.317 & 0.055 \\
Average & 0.291 & 0.195 & 0.096 \\
\hline
\end{tabular}

Notes: This table reports the results of decomposition in (10). The first column reports the actual correlation in the data.

could be large both because the directly connected firms account for the large share of the economy and/or because they exhibit larger correlations with the foreign country. Table 2 shows indeed that both of those things are true. However, the higher correlations reported for the directly connected firms in the table are not necessarily evidence of transmission of shocks. To isolate the role of the transmission of shocks, we next make use of the econometric estimation results.

We first compute, based on each firm's connectedness values, how much its correlation with each country would change if it were no longer connected to that country, as in (11). For all firms that are not connected at all to a particular country, this change is zero. We then aggregate according to (12). This equation takes into account the interaction between relative firm sizes $\left(w_{f}\right)$ and connectedness: the impact on aggregate comovement would be greater, all else equal, if the connected firms took up a larger share of aggregate value added.

Table 8 presents the results of computing the change in the aggregate correlation as in (12). It reports the actual correlation in the data, the predicted change in the correlation if none of the firms were connected, and the standard error for that predicted change in correlation. On average the aggregate correlation would decrease by about 0.098 if firms stopped being connected. By comparison, the mean actual observed correlation is 0.291 .

An interesting question is whether the change in aggregate correlation is driven by trade in goods or multinational linkages. Examining (11), it is clear that the change in aggregate correlation is simply additive in the weighted contribution of trade links (captured by the $E X$ and $I M$ coefficients) and the multinational links. Of course, these are not mutually exclusive for each firm, as a single firm can be in up to three of these categories at the same time. However, the breakdown of the aggregate effect into those two components can still be suggestive of the relative importance of those effects.

Columns 4-7 of Table 8 separate the contribution of trade linkages (denoted by $\Delta \rho_{A} \mid$ Trade $)$, and of the multinational linkages $\left(\Delta \rho_{A} \mid M N E\right)$ to aggregate comovement. It turns out that the bulk of the aggregate effect is due to trade. On average, trade linkages account for more than 90 percent of the total $(0.090$ out of 0.098$)$. 
Table 8-Changes in Aggregate Correlations

\begin{tabular}{|c|c|c|c|c|c|c|c|c|c|}
\hline Country & $\begin{array}{l}\rho_{A} \\
(1)\end{array}$ & $\begin{array}{l}\Delta \rho_{A} \\
(2)\end{array}$ & $\begin{array}{c}\operatorname{SE}\left(\Delta \rho_{A}\right) \\
\text { (3) }\end{array}$ & $\begin{array}{c}\Delta \rho_{A} \mid \text { Trade } \\
\text { (4) }\end{array}$ & $\begin{array}{c}\operatorname{SE}\left(\Delta \rho_{A} \mid \text { Trade }\right) \\
(5)\end{array}$ & $\begin{array}{c}\Delta \rho_{A} \mid M N E \\
\text { (6) }\end{array}$ & $\begin{array}{c}\operatorname{SE}\left(\Delta \rho_{A} \mid M N E\right) \\
\text { (7) }\end{array}$ & $\begin{array}{c}\Delta \rho_{A} \mid E q . W \\
(8)\end{array}$ & $\begin{array}{c}\operatorname{SE}\left(\Delta \rho_{A} \mid E q \cdot W\right) \\
(9)\end{array}$ \\
\hline Belgium & 0.758 & -0.112 & 0.016 & -0.105 & 0.010 & -0.007 & 0.013 & -0.035 & 0.002 \\
\hline Brazil & -0.269 & -0.053 & 0.011 & -0.049 & 0.006 & -0.004 & 0.009 & -0.005 & 0.000 \\
\hline China & -0.545 & -0.079 & 0.015 & -0.075 & 0.007 & -0.005 & 0.013 & -0.014 & 0.001 \\
\hline Germany & 0.643 & -0.117 & 0.019 & -0.106 & 0.010 & -0.011 & 0.016 & -0.035 & 0.002 \\
\hline Italy & 0.630 & -0.110 & 0.019 & -0.101 & 0.010 & -0.009 & 0.016 & -0.033 & 0.002 \\
\hline Japan & -0.183 & -0.077 & 0.011 & -0.073 & 0.008 & -0.004 & 0.009 & -0.011 & 0.001 \\
\hline Netherlands & 0.618 & -0.105 & 0.014 & -0.095 & 0.009 & -0.010 & 0.011 & -0.025 & 0.002 \\
\hline Spain & 0.876 & -0.103 & 0.019 & -0.095 & 0.009 & -0.008 & 0.017 & -0.028 & 0.002 \\
\hline UK & 0.010 & -0.111 & 0.019 & -0.099 & 0.009 & -0.012 & 0.016 & -0.027 & 0.002 \\
\hline USA & 0.372 & -0.117 & 0.019 & -0.101 & 0.010 & -0.016 & 0.016 & -0.025 & 0.002 \\
\hline Average & 0.291 & -0.098 & & -0.090 & & -0.009 & & -0.024 & \\
\hline
\end{tabular}

Notes: This table reports the results of the aggregation exercise in (12). The column labeled $\mathrm{SE}\left(\Delta \rho_{A}\right)$ reports the standard error associated with the estimated change in aggregate correlation. Columns 4-7 present the change in the correlation due to severing of trade linkages and multinational linkages separately, along with corresponding standard errors. Columns 8 and 9 present the change in the correlation due to severing of direct linkages assuming that all firms have equal size, along with corresponding standard errors.

Finally, we check to what extent the fact that the largest firms tend to be systematically more internationally connected contributes to the aggregate impact of direct linkages. To that end, we construct the change in the aggregate comovement that would obtain if all firms were of equal size: $w_{f}=1 / N \forall f$ in (12), with $N$ the total number of firms. The results are presented in columns 8-9 of Table 8, labeled $\Delta \rho_{A} \mid E q . W$. The change in the aggregate correlation is substantially smaller, 0.024 . That is, the fact that the larger firms are systematically more likely to exhibit international linkages roughly quadruples the impact of direct linkages on international comovement.

Online Appendix Table A8 presents the results separately for the manufacturing and the nonmanufacturing sectors. In the manufacturing sector, the impact is larger in absolute terms, with the severing of direct linkages leading to a fall in correlation of 0.103 on average, relative to the mean observed correlation of 0.484 . For the nonmanufacturing sector, the absolute impact is more modest at -0.063 , but the correlation of the nonmanufacturing sector with the foreign countries is also lower, at 0.111 on average.

We now compute the change in aggregate correlation taking indirect linkages into account. While the direct linkage coefficients are remarkably similar in the manufacturing and nonmanufacturing samples, online Appendix Table A6 reveals that upstream and downstream indirect linkage coefficients exhibit quite different patterns in these two sets of firms. Our aggregation exercise thus takes this heterogeneity into account, by applying subsample-specific coefficients to the $D S_{f, j, \mathcal{C}}$ and $U S_{f, j, \mathcal{C}}$ terms for manufacturing and nonmanufacturing firms. 14

Columns 2 and 3 of Table 9 report the results. The predicted change in aggregate correlation is now larger at -0.199 . Columns $4-9$ break down the change in

\footnotetext{
${ }^{14}$ Precisely, we run a regression on the whole sample, but allowing $D S_{f, j, \mathcal{C}}$ and $U S_{f, j, \mathcal{C}}$ and country fixed effects to differ for manufacturing and nonmanufacturing firms. The results (not reported to conserve space) are very similar to the coefficients in online Appendix Table A6.
} 
Table 9-Changes in Aggregate Correlations, Including Indirect Effects

\begin{tabular}{|c|c|c|c|c|c|c|c|c|c|}
\hline Country & $\begin{array}{l}\rho_{A} \\
(1)\end{array}$ & $\begin{array}{c}\Delta \rho_{A} \\
(2)\end{array}$ & $\begin{array}{c}\operatorname{SE}\left(\Delta \rho_{A}\right) \\
\text { (3) }\end{array}$ & $\begin{array}{c}\Delta \rho_{A} \mid \\
\text { Direct } \\
\quad(4)\end{array}$ & $\begin{array}{c}\operatorname{SE}\left(\Delta \rho_{A} \mid\right. \\
\text { Direct }) \\
(5)\end{array}$ & $\begin{array}{c}\Delta \rho_{A} \mid \\
\text { Indirect, } \\
\text { Manuf } \\
(6)\end{array}$ & $\begin{array}{c}\operatorname{SE}\left(\Delta \rho_{A} \mid\right. \\
\text { Indirect, } \\
\text { Manuf }) \\
(7)\end{array}$ & $\begin{array}{c}\Delta \rho_{A} \mid \\
\text { Indirect, } \\
\text { Non-Manuf } \\
(8)\end{array}$ & $\begin{array}{c}\mathrm{SE}\left(\Delta \rho_{A} \mid\right. \\
\text { Indirect, } \\
\text { Non-Manuf }) \\
\text { (9) }\end{array}$ \\
\hline Belgium & 0.758 & -0.263 & 0.029 & -0.093 & 0.016 & -0.223 & 0.020 & 0.053 & 0.015 \\
\hline Brazil & -0.269 & -0.074 & 0.012 & -0.044 & 0.011 & -0.048 & 0.004 & 0.018 & 0.004 \\
\hline China & -0.545 & -0.272 & 0.031 & -0.098 & 0.019 & -0.218 & 0.020 & 0.044 & 0.014 \\
\hline Germany & 0.643 & -0.254 & 0.029 & -0.092 & 0.019 & -0.201 & 0.019 & 0.039 & 0.013 \\
\hline Italy & 0.630 & -0.121 & 0.015 & -0.063 & 0.012 & -0.081 & 0.007 & 0.024 & 0.006 \\
\hline Japan & -0.183 & -0.216 & 0.023 & -0.088 & 0.014 & -0.163 & 0.015 & 0.035 & 0.011 \\
\hline Netherlands & 0.618 & -0.121 & 0.015 & -0.063 & 0.012 & -0.081 & 0.007 & 0.024 & 0.006 \\
\hline Spain & 0.876 & -0.222 & 0.028 & -0.085 & 0.019 & -0.181 & 0.016 & 0.045 & 0.012 \\
\hline UK & 0.010 & -0.230 & 0.027 & -0.094 & 0.019 & -0.176 & 0.016 & 0.040 & 0.012 \\
\hline USA & 0.372 & -0.221 & 0.026 & -0.100 & 0.019 & -0.159 & 0.014 & 0.038 & 0.011 \\
\hline Average & 0.291 & -0.199 & & -0.082 & & -0.153 & & 0.036 & \\
\hline
\end{tabular}

Notes: This table reports the results of the aggregation exercise in (12), augmented with indirect linkages. The column labeled $\operatorname{SE}\left(\Delta \rho_{A}\right)$ reports the standard error associated with the estimated change in aggregate correlation. The last six columns present the change in the correlation due to severing of direct linkages and indirect linkages separately, along with corresponding standard errors. The results are based on estimation that allows coefficients on $D S_{f, j, \mathcal{C}}$ and $U S_{f, j, \mathcal{C}}$ as well as country fixed effects to differ in manufacturing and nonmanufacturing sectors.

the aggregate correlation into the components due to direct and indirect linkages. ${ }^{15}$ Because $D S_{f, j, \mathcal{C}}$ and $U S_{f, j, \mathcal{C}}$ coefficients differ across the two subsamples, we report the aggregate contributions of indirect linkages separately for manufacturing and nonmanufacturing. Direct linkages account for an average of -0.082 of the -0.199 total effect.

Indirect linkages together actually contribute more than one-half of the overall effect, -0.117 on average. The entire contribution of indirect linkages to increasing comovement is driven by the manufacturing subsample, which is responsible for a -0.153 correlation change if links are severed. The point estimate of the indirect linkage contribution in the nonmanufacturing sample is actually positive, implying that the nonmanufacturing indirect links lower comovement, by 0.036 on average. We do not draw sharp conclusions from either the sign or the size of this effect, as the nonmanufacturing indirect linkage coefficient estimates are not reliable. Online Appendix Table A6 shows that the signs of the coefficients on the two indirect linkage coefficients are not even stable across country and country $\times$ sector effects. All in all, however, we find a strong and robust positive contribution of indirect linkages to comovement, driven by the manufacturing sector.

\section{Conclusion}

In order to understand fluctuations at the macro level, we must understand micro-level behavior. This paper applies this principle to international businesscycle comovement by analyzing this phenomenon at the firm level. Because the largest firms are the most likely to exhibit direct cross-border linkages, we show that the internationally connected firms account for over one-half of French aggre-

\footnotetext{
${ }^{15}$ This exercise uses the direct linkage coefficients from the specification that includes indirect linkages, and thus column 4 of Table 9 does not match exactly column 2 of Table 8 (though it is close).
} 
gate value added. We next show that they are more correlated with the countries to which they are directly connected through trade and ownership links. Combining the two, if direct linkages were severed the aggregate correlations would fall by about one-third of the observed aggregate correlations in the data. We provide evidence of downstream linkages as well: firms that buy inputs from French firms that import from foreign markets tend to be more correlated with those foreign markets. Direct and indirect linkages combined can account for two-thirds of the observed aggregate comovement between the overall French economy and its trading partners.

\section{REFERENCES}

Acemoglu, Daron, Ufuk Akcigit, and William Kerr. 2016. "Networks and the Macroeconomy: An Empirical Exploration.” In NBER Macroeconomics Annual 2015, Vol. 30, edited by Martin Eichenbaum and Jonathan Parker, 276-335. Chicago: University of Chicago Press.

Acemoglu, Daron, Vasco M. Carvalho, Asuman Ozdaglar, and Alireza Tahbaz-Salehi. 2012. "The Network Origins of Aggregate Fluctuations.” Econometrica 80 (5): 1977-2016.

-Alessandria, George, and Horag Choi. 2007. "Do Sunk Costs of Exporting Matter for Net Export Dynamics?" Quarterly Journal of Economics 122 (1): 289-336.

Arkolakis, Costas, and Ananth Ramanarayanan. 2009. "Vertical Specialization and International Business Cycle Synchronization.” Scandinavian Journal of Economics 111 (4): 655-80.

-Atalay, Enghin. 2017. "How Important Are Sectoral Shocks?" American Economic Journal: Macroeconomics 9 (4): 254-80.

Backus, David K., Patrick J. Kehoe, and Finn E. Kydland. 1995. "International Business Cycles: Theory and Evidence.” In Frontiers of Business Cycle Research, edited by Thomas Cooley, 331-56. Princeton: Princeton University Press.

Baqaee, David Rezza. 2016. "Cascading Failures in Production Networks." https://dl.dropboxusercontent. com/content_link/x3lizOnp1Nr1Bgvlv4RkDaBc5ih8NSzITOqKGCTTu676OSBKVI02rbx5oz6Zx H7e/file (accessed November 11, 2017).

Baxter, Marianne, and Michael A. Kouparitsas. 2005. "Determinants of Business Cycle Comovement: A Robust Analysis.” Journal of Monetary Economics 52 (1): 113-57.

Blonigen, Bruce A., Jeremy Piger, and Nicholas Sly. 2014. "Comovement in GDP Trends and Cycles among Trading Partners.” Journal of International Economics 94 (2): 239-47.

Boehm, Christoph E., Aaron Flaaen, and Nitya Pandalai-Nayer. 2015. "Input Linkages and the Transmission of Shocks: Firm-Level Evidence from the 2011 Tohoku Earthquake.” Board of Governors of the Federal Reserve System Finance and Economics Discussion Series 2015-94.

-Burstein, Ariel, Christopher Kurz, and Linda Tesar. 2008. "Trade, Production Sharing, and the International Transmission of Business Cycles.” Journal of Monetary Economics 55 (4): 775-95.

Calderon, Cesar, Alberto Chong, and Ernesto Stein. 2007. "Trade Intensity and Business Cycle Synchronization: Are Developing Countries Any Different?" Journal of International Economics 71 (1): 2-21.

Carvalho, Vasco M. 2010. "Aggregate Fluctuations and the Network Structure of Intersectoral Trade." http://vasco-m-carvalho.github.io/pdfs/carvalho_aggregate_fluctuations_nets.pdf (accessed November 11, 2017).

-Carvalho, Vasco M., and Xavier Gabaix. 2013. "The Great Diversification and Its Undoing.” American Economic Review 103 (5): 1697-1727.

Carvalho, Vasco M., and Basile Grassi. 2015. "Large Firm Dynamics and the Business Cycle.” CEPR Discussion Paper 10587.

Carvalho, Vasco M., Makoto Nirei, Yukiko U. Saito, and Alireza Tahbaz-Salehi. 2016. "Supply Chain Disruptions: Evidence from the Great East Japan Earthquake.” Columbia Business School Research Paper 17-5.

-Clark, Todd E., and Eric van Wincoop. 2001. "Borders and Business Cycles.” Journal of International Economics 55 (1): 59-85.

Cravino, Javier, and Andrei A. Levchenko. 2017. "Multinational Firms and International Business Cycle Transmission.” Quarterly Journal of Economics 132 (2): 921-62.

di Giovanni, Julian, and Andrei A. Levchenko. 2010. "Putting the Parts Together: Trade, Vertical Linkages, and Business Cycle Comovement." American Economic Journal: Macroeconomics 2 (2): 95-124. 
di Giovanni, Julian, and Andrei A. Levchenko. 2012. "Country Size, International Trade, and Aggregate Fluctuations in Granular Economies.” Journal of Political Economy 120 (6): 1083-132.

di Giovanni, Julian, Andrei A. Levchenko, and Isabelle Mejean. 2014. "Firms, Destinations, and Aggregate Fluctuations.” Econometrica 82 (4): 1303-340.

di Giovanni, Julian, Andrei A. Levchenko, and Isabelle Mejean. 2018. "The Micro Origins of International Business-Cycle Comovement: Dataset." American Economic Review. https://doi. org/10.1257/aer.20160091.

-Frankel, Jeffrey A., and Andrew K. Rose. 1998. "The Endogeneity of the Optimum Currency Area Criteria.” Economic Journal 108 (449): 1009-25.

-Friberg, Richard, and Mark Sanctuary. 2016. "The Contribution of Firm-Level Shocks to Aggregate Fluctuations: The Case of Sweden.” Economics Letters 147: 8-11.

Gabaix, Xavier. 2011. "The Granular Origins of Aggregate Fluctuations." Econometrica 79 (3): 733-72.

Ghironi, Fabio, and Marc J. Melitz. 2005. "International Trade and Macroeconomic Dynamics with Heterogeneous Firms." Quarterly Journal of Economics 120 (3): 865-915.

Grassi, Basile. 2016. "IO in I-O: Competition and Volatility in Input-Output Networks." https://docs. google.com/viewer?a=v\&pid=sites\&srcid=ZGVmYXVsdGRvbWFpbnxncmFzc2liYXNpbGV8Z 3g6NDBjMDIzYWJjODIOM2RhNA (accessed November 11, 2017).

-Imbs, Jean. 2004. "Trade, Finance, Specialization, and Synchronization." Review of Economics and Statistics 86 (3): 723-34.

-Imbs, Jean. 2006. “The Real Effects of Financial Integration.” Journal of International Economics 68 (2): 296-324.

-Johnson, Robert C. 2014. "Trade in Intermediate Inputs and Business Cycle Comovement." American Economic Journal: Macroeconomics 6 (4): 39-83.

Kalemli-Ozcan, Sebnem, Elias Papaioannou, and José-Luis Peydró. 2013. "Financial Regulation, Financial Globalization, and the Synchronization of Economic Activity." Journal of Finance 68 (3): 1179-1228.

Kalemli-Ozcan, Sebnem, Bent E. Sorensen, and Oved Yosha. 2001. "Economic Integration, Industrial Specialization, and the Asymmetry of Macroeconomic Fluctuations." Journal of International Economics 55 (1): 107-37.

Kleinert, Jorn, Julien Martin, and Farid Toubal. 2015. "The Few Leading the Many: Foreign Affiliates and Business Cycle Comovement." American Economic Journal: Macroeconomics 7 (4): 134-59.

-Kose, M. Ayhan, and Kei-Mu Yi. 2006. "Can the Standard International Business Cycle Model Explain the Relation between Trade and Comovement?" Journal of International Economics 68 (2): 267-95.

Kurz, Christopher, and Mine Z. Senses. 2016. "Importing, Exporting, and Firm-Level Employment Volatility." Journal of International Economics 98:160-75.

Liao, Wei, and Ana Maria Santacreu. 2015. "The Trade Comovement Puzzle and the Margins of International Trade." Journal of International Economics 96 (2): 266-88.

Magerman, Glenn, Karolien De Bruyne, Emmanuel Dhyne, and Jan Van Hoye. 2016. "Heterogeneous Firms and the Micro Origins of Aggregate Fluctuations.” National Bank of Belgium Working Paper 312 .

Morgan, Donald P., Bertrand Rime, and Philip E. Strahan. 2004. "Bank Integration and State Business Cycles." Quarterly Journal of Economics 119 (4): 1555-84.

Ng, Eric C. Y. 2010. "Production Fragmentation and Business-Cycle Comovement." Journal of International Economics 82 (1): 1-14. 